\title{
Fuzzy Logic Technique to Evaluation of Material Hardness, Specific Wear Resistance of Aluminium
}

\author{
Meenaakumari. M, Sangeetha. M, Subbulakshmi. K
}

\begin{abstract}
The composite material consists combination of materials which are having different physical and chemical properties. It consists of a base matrix which is the major component and reinforcements of different weight percentages. In this work a study on wear properties of Aluminium matrix which is reinforced with TiB2 and $\mathrm{Cr} 2 \mathrm{O} 3$ is carried out. The Aluminium 7071 matrix is reinforced with $8 \%$ TiB2 and 4\%, $6 \%$ of $\mathrm{Cr} 203$. The method used for manufacturing composite is stirr casting. The investigation of specific wear rate for the composite of different combinations is done using pin on disc method at various loads and velocity. The wear pattern is studied using scanning electron microscope image of worned surfaces. The wear rate is predicted using fuzzy model and compared with experimental values.
\end{abstract}

Keywords :Fuzzy,Annova,Analysis..

\section{INTRODUCTION}

Composite materials are an area where lot of studies have been conducted. Comparing to conventional materials it shows improved performance in material properties. Aluminium based composite material is a popular composite especially in automobile and aerospace field. The reason behind this is its availability, low manufacturing cost and ease of manufacturing. Among many of manfucturing methods stirr casting is the most popular manufacturing method for making composites.

Day to day mechanical parts in the machines are subject to wear and tear. In order to increase the reliability of the machine, the materials used in the machine should be wear resistant. Lot of study has been conducted on wear of aluminium composites. Aswin N (T. Kumar, Swamy, \& Chandrashekar, 2013) reported that graphite content will increase the wear resistance of the Aluminium 6063 compoasites. Dora (Prasad \& Shoba, 2014) made a study of the effect of $\mathrm{SiC}$ and Rice Husk Ash on Aluminium and found that those reinforcements will decrese the wear rate of Alumnium composites. Kanthavel (Kanthavel, Sumesh, \&Saravanakumar, 2016) reported that the incoperation of MoS2 improves the wear resistance and reduce friction.

Revised Manuscript Received on August 22, 2019.

Meenaakumari.M, Assistant Professor, Department of Electronics And Communication Engineering,, Bharath Institute of Higher Education and Research, Chennai, India meenumathi.m@gmail.com

Sangeetha.M, Assistant Professor, Department of Electronics And Communication Engineering,, Bharath Institute of Higher Education and Research, Chennai, India sang_gok@gmail.com

Subbulakshmi.K, ,AssistantProfessor,Department of Electronics And Communication Engineering,, Bharath Institute of Higher Education and Research, Chennai, India p.sudha50@gmail.com
Dinahara (Dinaharan, Murugan, \&Thangarasu, 2016) mad an observation that the presence of $\mathrm{TiC}$ lowers the wear rate for Aluminium 6082 composites. The incoperation of Si3N2, AlN and ZrB2 (N. M. Kumar, Kumaran, \&Kumaraswamidhas, 2016) improves wear rate and coefficient of friction for

Aluminium 2618 alloy.Harane (Rana, Badheka, \& Kumar, 2016) observed that better dispersion of B4C particle in Aluminium 7015 improves wear rate. Alwynkingsly (Ochieze, Nwobi-Okoye, \&Atamuo, 2017) improves the wear rate of Aluminium by incoperatingcowhorn ash. M adlan (Abdulwahab, Dodo, Suleiman, Gebi, \& Umar, 2017) improves the wear resitance of Aluminium by incoperating melon shell ash. A study made by pradeepsharma (P. Sharma, Paliwal, Garg, Sharma, \&Khanduja, 2017) found that the presence of graphite will improve the wear rate for aluminium 6061 composites. Vipin K sharma (V. K. Sharma, Singh, \& Chaudhary, 2017) reported an increase in wear resistance by incoperating fly ash in pure Aluminium. (Kundu, Roy, \& Mishra, 2013) made a regression model for predicting wear rate for Aluminium $\mathrm{SiC}, \mathrm{Al} 2 \mathrm{O} 3$ composites. A decrease in wear rate for Aluminium composites was observed by (Satyanarayana, Naidu, \&Babu, 2016) with the presence of Red mud as reinforcement. He also made a regression model and ANN model for predicting wear rate and found to be satisfactory with experimental results. Not much literature is available for the dry and wet wear rate of TiB2, Cr2O3 Aluminium 7071 composites.

Only little study has been carried out for developing models for predicting dry and wet wear rate. In this work an attempt has been made to study the wear rate of Aluminium 7071TiB2, Cr2O3 hybrid composite. A fuzzy model has been developed for predicting wear rate. This model will help to have better understanding of wear rate on this composite.[1-10]

\section{EXPERIMENTAL PROCEDURE}

\section{A. Material Selection and ManufacturingProcess}

The technique used in this work for preparing composite is liquid metallurgy technique. In this work Aluminium 7071 was selected as base matrix. $\mathrm{TiB}_{2}$ and $\mathrm{Cr}_{2} \mathrm{O}_{3}$ were selected as reinforcements for improving mechanical properites. Stirr casting was selected for preparing composite moulds. Aluminium ingot was melted by using 3 phase electric furnace. During melting there is a chance of atmospheric gases especially hydrogen to get absorbed to the liquid metal. So a little amount of Hexachloroethane (C2Cl6) was added into the

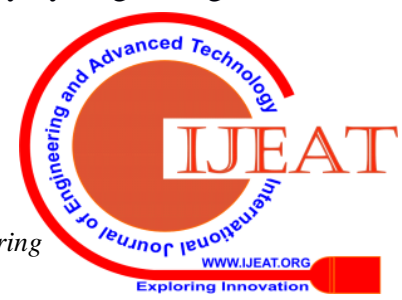


mould for absorbing dissolved gases. Reinforcement were also subjeted for preheating before mixing with the base material. Once Aluminium alloy was melted it was constantly stirredbyaironstirrat500rpm.Around $760^{\circ} \mathrm{C}$ thepreheated reinforcements were added to molten material and the mixture was agian stirred constantly at $500 \mathrm{rpm}$ for promoting uniform ditribution of reinforcements. Then the molt was poured to previously prepared metallic mould and was allowed for cooling. Later mould was removed for obtaining workpece of required dimension. The specimen were cut and machined to desired dimensions for hardness testing and weartesting.[11][12]

Table I: Weight Percentage in Samples

\begin{tabular}{|l|l|l|}
\hline Samples & $\begin{array}{l}\mathrm{TiB} 2 \\
\text { Weight } \\
\%\end{array}$ & $\begin{array}{l}\mathrm{Cr}_{2} \mathrm{O}_{3} \\
\text { Weight } \\
\%\end{array}$ \\
\hline Sample 1 & $8 \%$ & $4 \%$ \\
\hline Sample 2 & $8 \%$ & $6 \%$ \\
\hline
\end{tabular}

\section{B. Vickers hardnesstest}

The hardness of the composites was evaluated Brinell hardness tester. Prior to testing, test specimens cut out from each composite composition were polished to obtain a flat and smooth surface finish. Brinell hardness is determined by forcing a specified diameter hard steel or carbide sphere at specified load into the surface of a material for a time period. The hardness number can be calculated by dividing the load with area of indentation made on the surface. In this work a $500 \mathrm{~kg}$ load is applied to the specimen for 30 seconds. The test was repeated on each sample and average of the reading was taken as measure of hardness for thespecimen.[13-16]

\section{C.WearTesting}

The Pin-on-Disc apparatus (DUCOM) is used for wear testing. ASTM G99 G95a standard is followed for conducting wear test. Aluminium 7071 composite specimen of different weight perentage of reinforcements with dimension $10 \mathrm{~mm}$ diameter and $25 \mathrm{~mm}$ length were used for wear testing. The specimen and disc was throughly cleaned by using acetone before the test. The weight of the specimen before and after the test were noted. The load applied were $20,30,40,50 \mathrm{~kg}$, the velocity were $0.5,1,1.5$ and $2 \mathrm{~m} / \mathrm{s}$. The distance taken were 500, 1000, 1500 and $2000 \mathrm{~m}$. After each test the weight loss for the specimen were noted for calculating volume loss. The specific wear rate was calculated from the volume loss.[17-19]

\section{D.ANOVAAnalysis}

A taguchi table of L32 was selected as DOE. ANOVA analysis was done to find most influencing factor in the wear rate. The signal to noise ratio was also calculated for finding most optimized input parameters for minimum wearrate

Table 2

\begin{tabular}{|c|c|c|c|c|}
\hline Run & $\mathrm{Cr}_{2} \mathrm{O}_{3}$ wt $\%$ & Load $(\mathrm{N})$ & $\begin{array}{c}\text { Vel. } \\
(\mathrm{m} / \mathrm{s})\end{array}$ & $\begin{array}{r}\text { Dist. } \\
\text { (m) }\end{array}$ \\
\hline 1 & 4 & 20 & 0.5 & 500 \\
\hline 2 & 4 & 20 & 1 & 1000 \\
\hline 3 & 4 & 20 & 1.5 & 1500 \\
\hline 4 & 4 & 20 & 2 & 2000 \\
\hline 5 & 4 & 30 & 0.5 & 500 \\
\hline 6 & 4 & 30 & 1 & 1000 \\
\hline 7 & 4 & 30 & 1.5 & 1500 \\
\hline 8 & 4 & 30 & 2 & 2000 \\
\hline 9 & 4 & 40 & 0.5 & 1000 \\
\hline 10 & 4 & 40 & 1 & 500 \\
\hline 11 & 4 & 40 & 1.5 & 2000 \\
\hline 12 & 4 & 40 & 2 & 1500 \\
\hline 13 & 4 & 50 & 0.5 & 1000 \\
\hline 14 & 4 & 50 & 1 & 500 \\
\hline 15 & 4 & 50 & 1.5 & 2000 \\
\hline 16 & 4 & 50 & 2 & 1500 \\
\hline 17 & 6 & 20 & 0.5 & 2000 \\
\hline 18 & 6 & 20 & 1 & 1500 \\
\hline 19 & 6 & 20 & 1.5 & 1000 \\
\hline 20 & 6 & 20 & 2 & 500 \\
\hline 21 & 6 & 30 & 0.5 & 2000 \\
\hline 22 & 6 & 30 & 1 & 1500 \\
\hline 23 & 6 & 30 & 1.5 & 1000 \\
\hline 24 & 6 & 30 & 2 & 500 \\
\hline 25 & 6 & 40 & 0.5 & 1500 \\
\hline 26 & 6 & 40 & 1 & 2000 \\
\hline 27 & 6 & 40 & 1.5 & 500 \\
\hline 28 & 6 & 40 & 2 & 1000 \\
\hline 29 & 6 & 50 & 0.5 & 1500 \\
\hline 30 & 6 & 50 & 1 & 2000 \\
\hline 31 & 6 & 50 & 1.5 & 500 \\
\hline
\end{tabular}




\section{E. FuzzyModelling}

The input values load,velocity and distance were used in this model for predicting ouput specific wear rate.

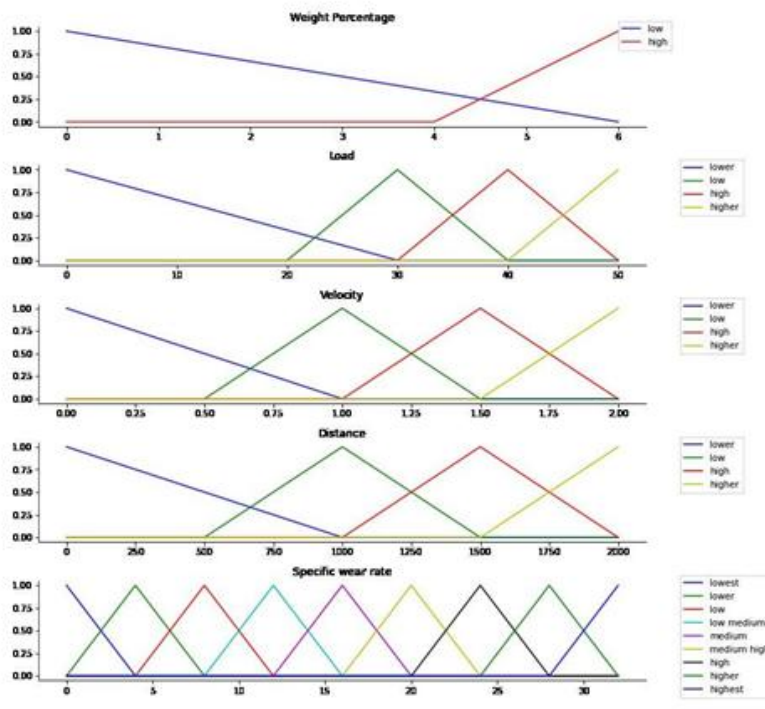

Fig 1. Membership Functions

The fuzzy linguistic variables used for expressing crisp input of these parameters are Low,Medium and High. The triangular memebership functions were used for converting crisp values to fuzzy values. A total of 32 rules were considered for the proposed mamdani fuzzy model interface system. These rules were used for predicting specific wear rate in the fuzzy model. The fuzzification and defuzzification was made using Python Scikit Fuzzy package. The rules are as follows

1. IF weight percentage is low AND load is lower AND velocity is lower AND distance is lower THEN specific dry wear rate is low

2. IF weight percentage is low AND load is lower AND velocity is low AND distance is low THEN specific dry wear rate is low.

3. IF weight percentage is low AND load is lower AND velocity is high AND distance is high THEN specific dry wear rate is medium.

4. IF weight percentage is low AND load is lower AND velocity is higher AND distance is higher THEN specific dry wear rate is high.

5. IF weight percentage is low AND load is lowAND velocity is lower AND distance is lower THEN specific dry wear rate is medium.

6. IF weight percentage is low AND load is low AND velocity is low AND distance is low THEN specific dry wear rate is medium high.

7. IF weight percentage is low AND load is lowAND velocity is high AND distance is high THEN specific dry wear rate ishigh.

8. IF weight percentage is low AND load is low AND velocity is higher AND distance is higher THEN specific dry wear rate is low.

9. IF weight percentage is low AND load is high AND velocity is lower AND distance is low THEN specific dry wear rate is medium high.

10. IF weight percentage is low AND load is high AND velocity is low AND distance is lower THEN specific dry wear rate is medium high.

11. IF weight percentage is low AND load is high AND velocity is high AND distance is higher THEN specific dry wear rate $\mathrm{i}$ slow.

12. IF weight percentage is low AND load is high AND velocity is higher AND distance is high THEN specific dry wear rate is low.

13. IF weight percentage is low AND load is higher AND velocity is lower AND distance is low THEN specific dry wear rate is mediumhigh.

14. IF weight percentage is low AND load is higher AND velocity is low AND distance is lower THEN specific dry wear rate is low.

15. IF weight percentage is low AND load is higher AND velocity is high AND distance is higher THEN specific dry wear rate is low.

16. IF weight percentage is low AND load is higher AND velocity is higher AND distance is high THEN specific dry wear rate is low.

17. IF weight percentage is high AND load is lower AND velocity is lower AND distance is higher THEN specific dry wear rate is low medium.

18. IF weight percentage is high AND load is lower AND velocity is low AND distance is high THEN specific dry wear rate is low medium.

19. IF weight percentage is high AND load is lower AND velocity is high AND distance is low THEN specific dry wear rate is low medium.

20. IF weight percentage is high AND load is lower AND velocity is higher AND distance is lower THEN specific dry wear rate is medium.

21. IF weight percentage is high AND load is low AND velocity is lower AND distance is higher THEN specific dry wear rate is medium.

22. IF weight percentage is high AND load is low AND velocity is low AND distance is high THEN specific dry wear rate is medium high.

23. IF weight percentage is high AND load is low AND velocity is high AND distance is low THEN specific dry wear rate is medium high.

24. IF weight percentage is high AND load is low AND velocity is higher AND distance is lower THEN specific dry wear rate is medium high.

25. IF weight percentage is high AND load is high AND velocity is lower AND distance is high THEN specific dry wear rate is medium high.

26. IF weight percentage is high AND load is high AND velocity is low AND distance is higher THEN specific dry wear rate is medium high.

27. IF weight percentage is high AND load is high AND velocity is high AND distance is lower THEN specific dry wear rate is medium high.

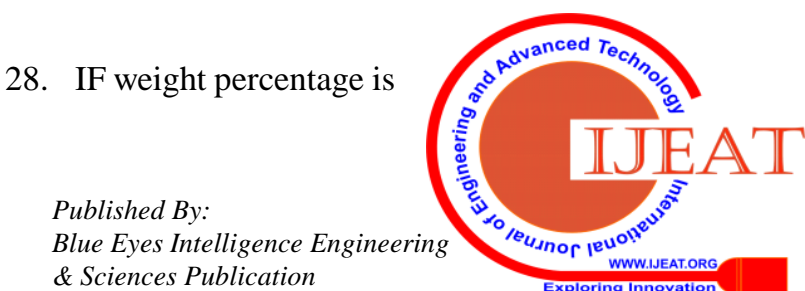


high AND load is high AND velocity is higher AND distance is low THEN specific dry wear rate is low.

29. IF weight percentage is high AND load is higher AND velocity is lower AND distance is high THEN specific dry wear rate is medium high.

30. IF weight percentage is high AND load is higher AND velocity is low AND distance is higher THEN specific dry wear rate is high.

31. IF weight percentage is high AND load is higher AND velocity is high AND distance is lower THEN specific dry wear rate is high.

32. IF weight percentage is high AND load is higher AND velocity is higher AND distance is low THEN specific dry wear rate is high.

The output derived from the model has to be unified and for this max-min interference method was selected. The output will be in the form of fuzzy values and this has to be defuzzified. The centroid of gravity method was used for defuzzification. The expression for calculating centre of gravity in defuzzification is given as:[20]

$$
\begin{aligned}
& \mathrm{x}=\int \mu(x) x d x \\
& \int \mu(x) d x
\end{aligned}
$$

\section{RESULT AND DISCUSSION}

The figure 2 shows the comparison of hardness values of specimens. It was found that the hardness of the specimen 2 is higher. Reason for this increase in hardness is due addition of more $\mathrm{Cr} 2 \mathrm{O} 3$ particles in Aluminium matrix.

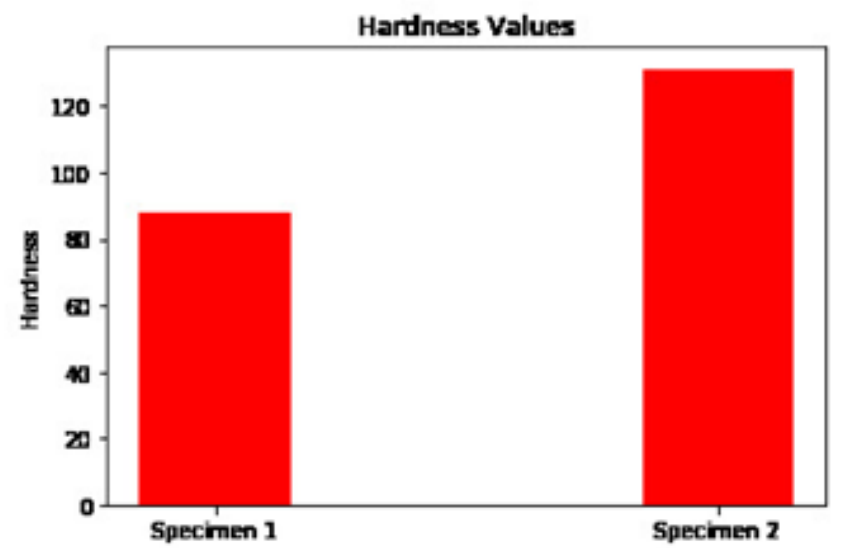

Table III: Specific Wear rate from experiment and fuzzy model

\begin{tabular}{|c|c|c|c|}
\hline Run & $\begin{array}{c}\text { Dry Sp Wear } \\
\text { rate } \times 10^{-5} \\
\left(\mathrm{~mm}^{3} / \mathrm{Nm}\right)\end{array}$ & S/N Ratio & $\begin{array}{c}\text { Predicted Dry Sp } \\
\text { Wear rate } \times 10^{-5} \\
\left(\mathrm{~mm}^{3} / \mathrm{Nm}\right)\end{array}$ \\
\hline 1 & 11.41 & -21.15 & 11.1818 \\
\hline 2 & 14.53 & -23.25 & 14.2394 \\
\hline 3 & 17.64 & -24.93 & 21.168 \\
\hline 4 & 22.01 & -26.85 & 26.412 \\
\hline 5 & 17.41 & -24.82 & 20.892 \\
\hline 6 & 21.32 & -26.58 & 25.584 \\
\hline 7 & 24.99 & -27.96 & 29.988 \\
\hline 8 & 27.58 & -28.81 & 33.096 \\
\hline 9 & 20.93 & -26.42 & 25.116 \\
\hline 10 & 21.44 & -26.62 & 21.0112 \\
\hline 11 & 27.33 & -28.73 & 26.7834 \\
\hline 12 & 27.59 & -28.82 & 27.0382 \\
\hline 13 & 21.45 & -26.63 & 1.021 \\
\hline 14 & 26.24 & -28.38 & 25.7152 \\
\hline 15 & 30.62 & -29.72 & 30.0076 \\
\hline 16 & 30.64 & -29.73 & 32.172 \\
\hline
\end{tabular}

\begin{tabular}{|c|c|c|c|}
\hline Run & $\begin{array}{c}\text { Dry Sp Wear } \\
\text { rate } \times 10^{-5} \\
\left(\mathrm{~mm}^{3} / \mathrm{Nm}\right)\end{array}$ & S/N Ratio & $\begin{array}{c}\text { Predicted Dry Sp } \\
\text { Wear rate } \times 10^{-5} \\
\left(\mathrm{~mm}^{3} / \mathrm{Nm}\right)\end{array}$ \\
\hline 17 & 10.5 & -20.42 & 11.025 \\
\hline 18 & 12.65 & -22.04 & 13.2825 \\
\hline 19 & 12.93 & -22.23 & 13.5765 \\
\hline 20 & 15.8 & -23.97 & 16.59 \\
\hline 21 & 16.79 & -24.5 & 17.6295 \\
\hline 22 & 19.55 & -25.82 & 20.5275 \\
\hline 23 & 20.73 & -26.33 & 21.7665 \\
\hline 24 & 20.5 & -26.24 & 21.525 \\
\hline 25 & 18.15 & -25.18 & 19.0575 \\
\hline 26 & 20.38 & -26.18 & 19.9724 \\
\hline 27 & 20.7 & -26.32 & 20.286 \\
\hline 28 & 22.75 & -27.14 & 22.295 \\
\hline 29 & 19.01 & -25.58 & 18.6298 \\
\hline 30 & 25.42 & -28.1 & 24.9116 \\
\hline 31 & 23.48 & -27.41 & 23.0104 \\
\hline 32 & 25.79 & -28.23 & 25.2742 \\
\hline
\end{tabular}

Table III shows the experiment values of specific wear rate for the specimens. The wear values from the experiment shows that wear rate increases with the weight percentage of $\mathrm{Cr} 2 \mathrm{O} 3$. This is due to increse in hadnesss of thematerial 


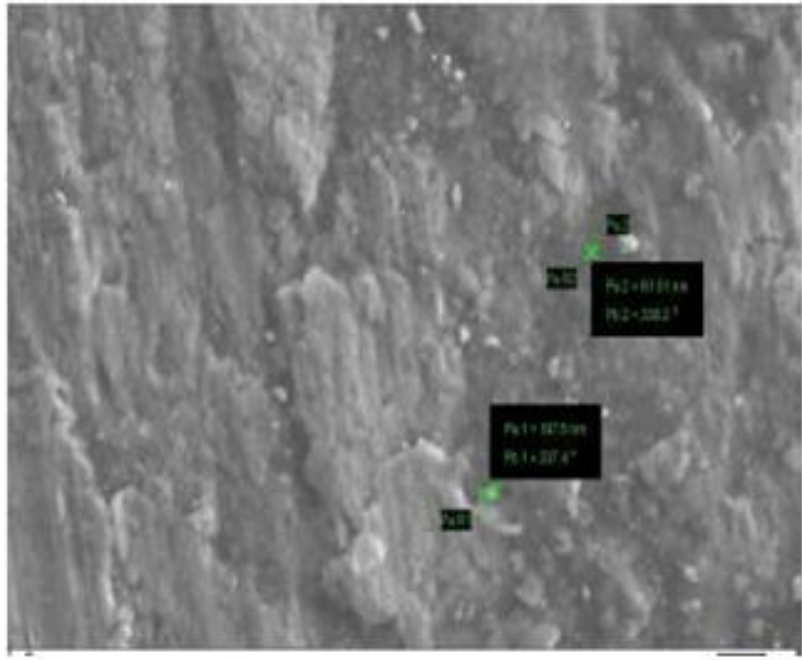

Fig 3. SEM image of Specimen 1

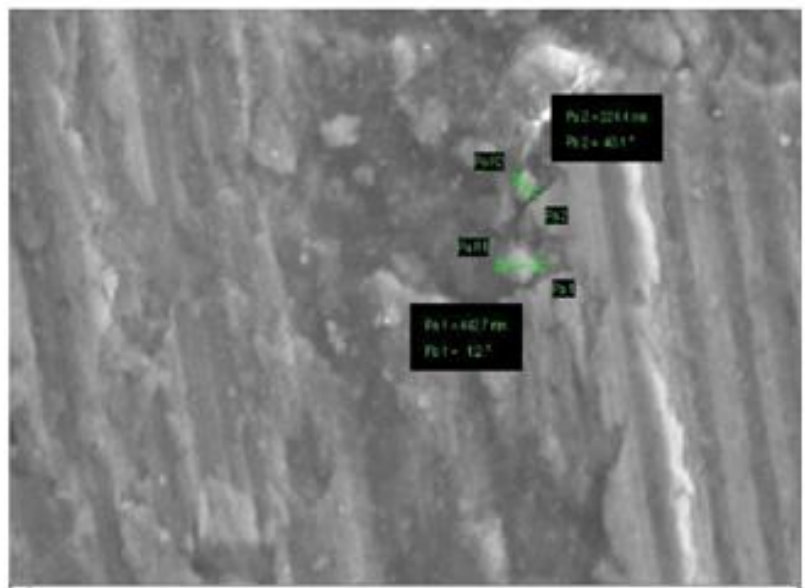

Figure 4. SEM image of Specimen 2

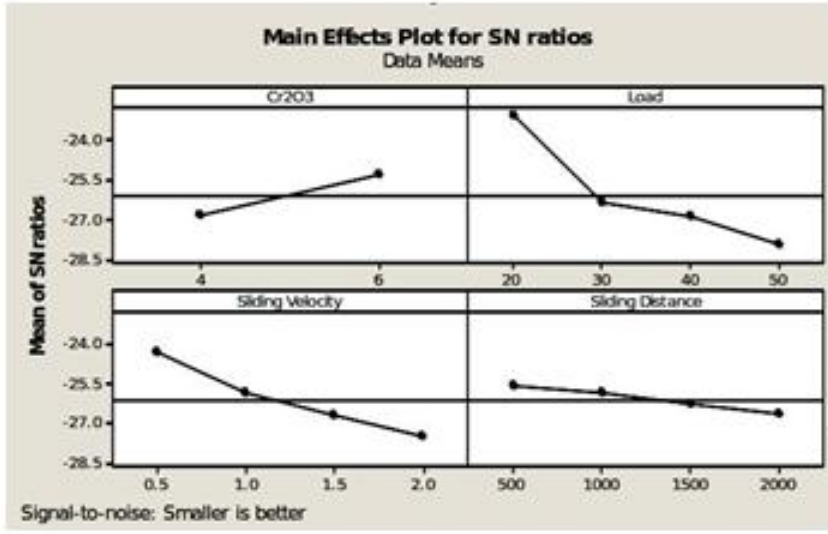

Fig 5. ANOVA Analysis

The anova analysis shows that most influencing factor in the experiment is weight percentage and less influencing factor is speed. The most optimized parameters are $\mathrm{Cr} 2 \mathrm{O} 38 \%$ weight percentage, Load is $20 \mathrm{~N}$,Sliding Velocity is $0.5 \mathrm{~m} / \mathrm{s}$ and Distance travelled is $500 \mathrm{~m}$

The results obtained from fuzzy model is matching with the experimental values. The average error in the predicted values is less

\section{CONCLUSION}

- Aluminium 7071-TiB2, Cr2O3 hybrid composite has been developed and characterization was carriedout.

- The investigation shows clearly that addition of $\mathrm{Cr} 2 \mathrm{O} 3$ increases the hardness of metal matrix composite.

- The ANOVA analysis was made for the specific wear rate of the material.

- The fuzzy model for predicting specific wear rate was successfully made.

. The fuzzy model predicted values which are closer to the experimental values.

\section{REFERENCES}

1. Gowri Sankaran, B., Karthik, B. \& Vijayaragavan, S.P. 2019, "Weight ward change region plummeting change for square based image huffman coding", International Journal of Innovative Technology and Exploring Engineering, vol. 8, no. 10, pp. 4313-4316.

2. Gowri Sankaran, B., Karthik, B. \& Vijayaragavan, S.P. 2019, "Image compression utilizing wavelet transform", International Journal of Innovative Technology and Exploring Engineering, vol. 8, no. 10, pp. 4305-4308.

3. Kandavel, N. \& Kumaravel, A. 2019, "Offloading computation for efficient energy in mobile cloud computing", International Journal of Innovative Technology and Exploring Engineering, vol. 8, no. 10, pp. 4317-4320.

4. Vinoth, V.V. \& Kanniga, E. 2019, "Reversible data hiding in encrypting images-an system", International Journal of Engineering and Advanced Technology, vol. 8, no. 6, pp. 3051-3053.

5. Selvapriya, B. \& Raghu, B. 2019, "Pseudocoloring of medical images: A research", International Journal of Engineering and Advanced Technology, vol. 8, no. 6, pp. 3712-3716.

6. Senthil Kumar, K. \& Muthukumaravel, A. 2019, "Bi-objective constraint and hybrid optimizer for the test case prioritization", International Journal of Engineering and Advanced Technology, vol. 8 , no. 6 , pp. 3436-3448.

7. Kavitha, G., Priya, N., Anuradha, C. \& Pothumani, S. 2019, "Read-write, peer-to-peer algorithms for the location-identity split", International Journal of Innovative Technology and Exploring Engineering, vol. 8, no. 9 Special Issue 3, pp. 445-447.

8. Kaliyamurthie, K.P., Michael, G., Anuratha, C. \& Sundaraj, B. 2019 , "Certain improvements in alzheimer disease classification using novel fuzzy c means clustering for image segmentation", International Journal of Innovative Technology and Exploring Engineering, vol. 8, no. 9 Special Issue 3, pp. 599-604.

9. Kaliyamurthie, K.P., Sundarraj, B., Geo, A.V.A. \& Michael, G. 2019 "RIB: Analysis of I/O automata", International Journal of Innovative Technology and Exploring Engineering, vol. 8, no. 9 Special Issue 3, pp. 1019-1022.

10. Velvizhi, R., Rajabhushanam, C. \& Vidhya, S.R.S. 2019, "Opinion mining for travel route recommendation using Social Media Networks (Twitter)", International Journal of Innovative Technology and Exploring Engineering, vol. 8, no. 9 Special Issue 3, pp. 508-512.

11. Kavitha, R., Sangeetha, S. \& Varghese, A.G. 2019, "Human activity patterns in big data for healthcare applications", International Journal of Innovative Technology and Exploring Engineering, vol. 8, no. 9 Special Issue 3, pp. 1101-1103.

12. Pothumani, S., Anandam, A.K., Sharma, N. \& Franklin, S. 2019, "Extended VEOT framework - Implemented in a smart boutique", International Journal of Innovative Technology and Exploring Engineering, vol. 8, no. 9 Special Issue 3, pp. 762-767.

13. Kaliyamurthie, K.P., Michael, G., Krishnan, R.M.V. \& Sundarraj, B. 2019, "Pseudorandom techniques for the internet", International Journal of Innovative Technology and Exploring Engineering, vol. 8 , no. 9 Special Issue 3, pp. 915-918.

14. Aravindasamy, R., Jeffrin Rajan, M., Rama, A. \& Kavitha, P. 2019 "Deep learning provisions in the matlab: Focus on CNN facility", International Journal of Innovative Technology and Exploring Engineering, vol. 8, no. 9 Special Issue 3, pp. 990-994.

15. Theivasigamani, S., Linda, M. \& Amudha, S. 2019, "Object sensing and its identification \& motion sensing", International Journal of Innovative Technology and Exploring Engineering, vol. 8, 
no. 9 Special Issue 3, pp. 545-549.

16. Mary Linda, I., Vimala, D. \& Shanmuga Priya, K. 2019, "A methodology for the emulation of IPv4", International Journal of Innovative Technology and Exploring Engineering, vol. 8, no. 9 Special Issue 3, pp. 848-852.

17. Velvizhi, R., Priya, D.J., Vimala, D. \& Linda, I.M. 2019, "Increased routing algorithm for mobile adhoc networks", International Journal of Innovative Technology and Exploring Engineering, vol. 8, no. 9 Special Issue 3, pp. 1606-1608

18. Sangeetha, S., Anuradha, C. \& Priya, N. 2019, "DNS in real world", International Journal of Innovative Technology and Exploring Engineering, vol. 8, no. 9 Special Issue 3, pp. 937-940.

19. Geetha, C., Vimala, D. \& Priya, K.S. 2019, "Constructing multi-processors and spreadsheets with SKIVE", International Journal of Innovative Technology and Exploring Engineering, vol. 8, no. 9 Special Issue 3, pp. 516-519.

20. Yugendhar, K., Sugumar, V. \& Kavitha, P. 2019, "A novel method of univac using fuzzy logic", International Journal of Innovative Technology and Exploring Engineering, vol. 8, no. 9 Special Issue 3, pp. 435-437.

21. Kaliyamurthie, K.P., Michael, G., Elankavi, R. \& Jijo, S.A. 2019 , "Implementing aggregate-key for sharing data in cloud environment using cryptographic encryption", International Journal of Innovative Technology and Exploring Engineering, vol. 8, no. 9 Special Issue 3, pp. 957-959.

22. Jeffrin Rajan, M., Aravindasamy, R., Kavitha, P. \& Rama, A. 2019, "A novel method of object orientation variation in $\mathrm{C}++$ and java", International Journal of Innovative Technology and Exploring Engineering, vol. 8, no. 9 Special Issue 3, pp. 708-710.

23. Nayak, R., Dinesh, S. \& Thirunavukkarasu, S. 2019, "A novel method improvement of rapid miner for the data mining applications", International Journal of Innovative Technology and Exploring Engineering, vol. 8, no. 9 Special Issue 3, pp. 457-460.

24. Sivaraman, K., Krishnan, R.M.V., Sundarraj, B. \& Sri Gowthem, S. 2019, "Network failure detection and diagnosis by analyzing syslog and SNS data: Applying big data analysis to network operations", International Journal of Innovative Technology and Exploring Engineering, vol. 8, no. 9 Special Issue 3, pp. 883-887.

25. Vimala, D., Linda, I.M. \& Priya, K.S. 2019, "Decoupling online algorithms from erasure coding in DNS", International Journal of Innovative Technology and Exploring Engineering, vol. 8, no. 9 Special Issue 3, pp. 950-953.

26. Rama, A., Kumaravel, A. \& Nalini, C. 2019, "Preprocessing medical images for classification using deep learning techniques", International Journal of Innovative Technology and Exploring Engineering, vol. 8, no. 9 Special Issue 3, pp. 711-716.

27. Sangeetha, S., Srividhya, S.R., Anita Davamani, K. \& Amudha, S. 2019, "A procedure for avoid overrun error in universal synchronous asynchronous receiver transmitter (usart) by utilizing dummy join and interrupt latency method", International Journal of Innovative Technology and Exploring Engineering, vol. 8, no. 9 Special Issue 3, pp. 657-660.

28. Aravindasamy, R., Jeyapriya, D., Sundarajan, B. \& Sangeetha, S. 2019, "Data duplication in cloud for optimal performance and security", International Journal of Innovative Technology and Exploring Engineering, vol. 8, no. 9 Special Issue 3, pp. 1156-1158.

29. Aravindasamy, R., Jeffrin Rajan, M., Sugumar, V. \& Kavitha, P. 2019 "A novel method on developing superblocks and the transistor using apodryal", International Journal of Innovative Technology and Exploring Engineering, vol. 8, no. 9 Special Issue 3, pp. 982-985.

30. Sasikumar, C.S. \& Kumaravel, A. 2019, "E-learning attributes selection through rough set theory and data mining", International Journal of Innovative Technology and Exploring Engineering, vol. 8, no. 10 , pp. $3920-3924$

\section{AUTHORS PROFILE}
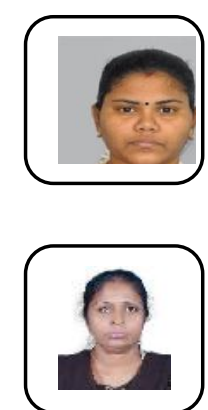
Electronics And Communication Engineering,, Bharath Institute of Higher Education and Research, Chennai, India

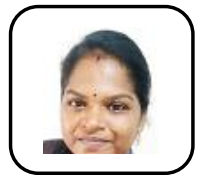

Subbulakshmi.K ,AssistantProfessor,Department of Electronics And Communication Engineering,, Bharath Institute of Higher Education and Research, Chennai, India 